\title{
Demystify Civic Education through the Educational Neuroscience on Indonesia Curriculum
}

\author{
Fauzi Abdillah \\ Department of Pedagogy \\ Universitas Pendidikan Indonesia \\ Bandung, Indonesia \\ abdillah@upi.edu
}

\begin{abstract}
This article investigates and identify the neurobiological basis of Civic Education learning outcomes in our social brain processes. Pancasila as a state ideology of Indonesia have included on civic education in Indonesia education curriculum as known as Pancasila and Civic Education (PPKn). On this subject the neurobiological basis for assessing the successfulness of the educational processes are not included as learning outcomes, especially in elementary school context. Based on interpretive philosophical approach with hermeneutic methods, result of the study recommend that PPKn move to alternative curriculum framework and perspective of assessment related to Educational Neuroscience for enhancing evidencebased education policy. For the long run, educational neuroscience will contribute to the practices and evidence-based policy, especially for civic education curriculum in Indonesia.
\end{abstract}

Keywords- civic education; educational neuroscience; evidence-based education policy

\section{INTRODUCTION}

Education stands on a philosophical basis throughout the course of institutionalization of education in Indonesia. The evaluation and assessment system derive from that philosophical base. This is a historical and political consequence of the national condition of each era.

The level of actors ranging from personal to organizational, with diverse interests at the local to national levels. However, the importance of encouraging the nation's philosophical base of education, known in Indonesia, was initiated by local educational leaders such as $\mathrm{Ki}$ Hadjar Dewantara with Tamansiswa and Muhammad Sjafei with INS Kayu Tanam. Both stand on a philosophical basis which is full of liberation, value, and local wisdom.

Ki Hadjar Dewantara popularized the culture-based education that was implemented in Tamansiswa, and finally enliven the education practice and policy in Indonesia afterward. [1] The foundation of Tamansiswa is known as the leadership philosophy of the Student which contains Ing ngarso sung tulodo, ing madyo mangun karso, tut wuri handayani, which means being an example in the front, being a motivation in the middle and being a support in the back.

On the other hand, the philosophy of INS Kayu Tanam rests on the nature of the child. Muhammad Sjafei formulated two educational goals, namely the goal of permanent education or ultimate goal, and educational goals that can change by adjusting the needs of the times. By elaborating educational thinking on an ecological, political and cultural basis, Sjafei stood on the concept of a functioning human being [2]. Education to liberate is the basis agreed upon by the two educational pioneers of Indonesia.

At least, from many ideas of educational leaders, both have an effect on the praxis and education policy in Indonesia in the future. On the other hand, both of them had also occupied government political position. Thus, his thinking was also reflected in policies for education, from educational philosophy to praxis, such as pedagogy to educational assessment.

Then, how is the assessment and evaluation of education to be practiced nowadays? Is it still referring to the thought of $\mathrm{Ki}$ Hadjar Dewantara and Muhammad Sjafei?

An interdisciplinary trend also affects increasingly integrative educational practices such as educational neuroscience. Where we can see cognitive processes from the point of view of neural processes. Although in practice, we do not perform any surgery as in medic [3].

In particular, there is the social area of the brain, which has responsibility for metallization and social cognitive processes. Specifically is in solitude part [4]. Based on that point, we can see how neuroscience evolves with its own goals and ways according to the implemented practice including in education. References in educational processes engaging in learning outcomes are also somewhat influenced by them.

So far, Civic Education mostly refers to [5] what we call civic competences, among others: civic knowledge, civic skills, and civic dispositions. These three things are both dimension and learning outcomes in Civic Education. Then, how to measure these three things? And from where these three things are contextually sourced and referring to?

Komalasari uses Value Clarification Technique (VCT) for evaluation in Civic Education. By implementing living values in the Civic Education [6,7], it affirms that Civic Education is largely dominated by such broad and deep philosophy.

The debate over the definition, which aspect to be the reference, country or culture? All of these become the characteristics that often brought on the discussion of civic 
outcomes is more concerned with philosophy. So far, Civic Education and other subjects in Indonesia use authentic evaluation assessment in accordance with Ministry of Education Decree No. 103 of 2014. In addition, there are other options as well as with institutional assessment or systematic assessment. [8] In order to implement the measurement in education with multiple purposes of use at various levels of schools.

While in other scholarships, the Educational Neuroscience, the discourse in the assessment has grown rapidly due to the need of juxtaposing empirical data rather than the jargon of brain-based which contains the claim. This is closer to a myth difficult to be scientifically accountable [9]. Although, in neuroscience, it has to be distinguished radically between mind and brain because both are different concepts. Thus, there will be no misconception. Based on the same reason, the discourse on the use of neuroscience for education was discussed in the late 90 's in the USA, after previously used limited in the medical realm [10], because of his scientific case earlier. Skeptically, there are some people who are concerned about the imbalance results between large effort and resource to do more investigation into educational neuroscience, but there are only a few results and effectiveness that can be exploited [11].

\section{METHODS}

As a preliminary research, this article using interpretive philosophical approach with hermeneutic methodology that interpreted and integrated human interest into a study through mainly focuses on the latest educational research and policy literature.

\section{FINDINGS}

\section{A. Philosophical basis vs. Neurobiological basis: where does the civic education stand?}

Civic Education is built in multidisciplinary, in which there are studies and applied science of psychology, education, politics, law, culture, sociology, technology, and economics. They operate in a multidisciplinary, transdisciplinary, and interdisciplinary in the theoretical as well as praxis area.

The educational environment is complex including the Civic Education. It is one of the elements as well as the structure in the learning and education. Thus, it is necessary to separate paradigm to see, apply and develop it. The three modes are much more philosophical than other bases comparing to the Neurobiology in particular.

It is now a new scene in Civic Education due to its requirement to directly maneuver into areas that have not been explored for the sake of praxis. For example are Neuroscience and biology. Both of these have a quite different methodology from education as a social discipline. [12] In the meantime, this leads us to empirical evidence, which can be directly seen to the extent of educational strategy that can be measured more precisely.

This offer becomes more interesting. The project of Civic Education objectivity is aimed to be fairer and can be more clearly measured.

\section{B. Educational neuroscience, neuroducation or neuropedagogy: which one is for civic education?}

Certainly, the initial identity of Civic Education, which develops and operates from a philosophical base, does not have to be abandoned or undone. The next question may be, which variant is more suitable for Civic Education in this mode?

There are at least three offers in the concept of Brain, Mind and Education, namely Educational Neuroscience, Neuroeducation and Neuropedagogy. Although both are based on brain studies, all three have different praxis and paradigm respectively.

Educational Neuroscience is seen as a bridge between the differences in knowledge of how neural functions are and how these functions operate in teaching or learning. Therefore understand that educational neuroscience is part of neuroscience $[12,13]$. While Neuroeducation is more viewed as an interdisciplinary arena that combines studies of neuroscience, education, and psychology to enhance the learning approach. [3] With such definition, it looks very much like the Neuroeducational concept of [14] that integrates through its comprehensive approach to the needs of educational praxis. And finally, Neuropedagogy stands on the needs of teachers and students as lifelong learners of superior emotional activity and experiences as teachers or learners [13].

From the ontological studies, we will most likely ask what terminology Civic Education can refer to. All of the three are able to develop on the praxis of Civic Education which stretches from elementary school to college. But in the context of the school, we can see that Educational Neuroscience can be a clear base because it is based on empirical data on how neural works in a micro-teaching activity in each subject. Of course, this starting point will pave the way for Neuropedagogy until Neuroeducation can be developed through the mode and perspective of Civic Education at every level of education. Such sustainability needs to be strengthened in the curriculum and practice of education.

The curriculum focuses on applying practical knowledge [15]. Certainly, the research results from neuroscience, especially those that are practically called educational neuroscience also need to be practiced. The reason is that it can also be the knowledge to be practiced someday. In Civic Education, to measure and evaluate the extent to which the success of education and learning can be seen from the achievement of its objectives.

From the above explanation, we need to take into account at least three challenges in applying educational neuroscience to the curriculum, namely the extent of its relevance, the philosophical basis (regarding conceptual clarity, epistemological interest, and reductionism), and usefulness in educational praxis [16].

Regarding the relevance and usefulness of educational praxis, of course, we can refer to the results of educational neuroscience research that we discussed earlier. The basis of its philosophy should be discussed more intense and deeper in Civic Education. The reason is that the meeting between the colossal base of Civic Education, namely the philosophy of education and the philosophy of the nation-state becomes a 
vital element. Moreover, related to ethics and morals, in the future, there will be the more friendly debate on this topic. In order to be the reference to design education policy. Which is not only running in the arena of philosophy but also the neurobiological arena in the process of education and learning.

\section{CONCLUSIONS}

\section{A. Where will the civic education credentials be?}

As discussed earlier, Civic Education is on the basis of philosophy, for example, political philosophy, moral philosophy, philosophy of the Indonesian nation-state, and other philosophies. That base is what develops Civic Education until it becomes what it is today in Indonesian education.

The offer for Civic Education to move to educational neuroscience for the implementation of education in the richer areas of empirical data finds its urgency. Thus, the balance can be reconciled between the base of philosophy and its neurobiological base.

Of course, the philosophy of education does not stand alone but also need to have another base that is based on evidence, which is observing what happens at the center of thinking activity namely the brain. In order to be more measurable, this is certainly what we call educational neuroscience.

From previous ontological exploration, we understand that Neuropedagogy, Neuroeducation and Educational neuroscience make it possible to thrive on the Practice of Civic Education that spans from elementary school through college. But in the context of the school, we can see that Educational Neuroscience can be a clear base. It is based on empirical data on how neural works in a micro-teaching activity in each subject. Of course, this starting point will pave the way for neuropedagogy until neuroeducation can be developed from the perspective of Civic Education.

\section{REFERENCES}

[1] Towaf , S. M., The National Heritage of Ki Hadjar Dewantara in Tamansiswa About Culture-Based Education and Learning. Journal of Education and Practice, 7(23), pp. 167-176. 2016.

[2] Zed, M., Engku Mohammad Sjafe'i dan INS Kayutanam: Jejak Pemikiran Pendidikannya. Tingkap, 8(2), pp. 173-188. 2012.

[3] Clark, J., Philosophy, Neuroscience and Education. Educational Philosophy and Theory, 47(1), pp. 1-11. 2013.

[4] Hawkley, L. C. \& Cacioppo, J. T., Loneliness matters: A theoretical and empirical review of consequences and mechanisms.. Annuals of Behavioral Medicine, Volume 40, p. 218-227. 2010.

[5] Branson, M. S., The Role of Civic Education. Calabas: Center for Civic Education. 1998.

[6] Komalasari, K., The Living Values-Based Contextual Learning to Develop the Students' Character. Journal of Social Sciences 8, pp. 246251. 2012.

[7] Komalasari, K. \& Sapriya, Living Values Education in Teaching Materials to Develop Students' Civic Disposition. The New Educational Review, 44(2), pp. 107-121. 2016.

[8] Hatcher, J. A., Assessing Civic Knowledge and Engagement. New Directions For Institutional Research, Issue 149, pp. 81-92. 2011.

[9] Kelly, A. E., Can Cognitive Neuroscience Ground a Science of Learning?. Educational Philosophy and Theory,, 43(1), pp. 17-23. 2011.

[10] Geake, J., Cognitive neuroscience and education: two-way traffic or one-way street?. Westminster Studies in Education, 27(1), pp. 87-98. 2004.

[11] Snook, I., Educational Neuroscience: A plea for radical scepticism. Educational Philosophy and Theory, 44(5), pp. 445-449. 2012.

[12] Meulen, A. v. d., Krabbendam, L. \& Ruyter, D. d., Educational Neuroscience: Its Position, Aims and Expectations. British Journal of Educational Studies, 63(2), pp. 229-243. 2015

[13] Patten, K. E., The Somatic Appraisal Model of Affect: Paradigm for Educational Neuroscience and Neuropedagogy. Educational Philosophy and Theory, 43(1), p. 87-97. 2011.

[14] Howard-Jones, P. A., A Multiperspective Approach to Neuroeducational Research. Educational Philosophy and Theory,, 43(1), pp. 24-30. 2011.

[15] Lovat, T. \& Smith, D., Curriculum: Action on reflection. Melbourne: Thomson. 2003

[16] Clement, N. D. \& Lovat, T., Neuroscience and Education: Issues and Challenges for Curriculum. Curriculum Inquiry, 42(4), pp. 534-557. 2012 